\title{
Literatur (kepustakaan) keislaman dalam konteks pesantren
}

Musrifah

\begin{abstract}
Universally, Islamic literature existing in boarding schools is preserved and passed down from generation to generation directly related to the religious sciences as inherited to Islamic society by past priests in the past called "yellow books". The books cover very short text to text composed of bold volumes of Arabic Grammar, Tajwid, Logic, Fiqh and Ushul Fiqh, Aqidah, Tafsir of the Qur'an, Hadith and Hadith Science, Morals and Sufism, History of Life Prophet and a tribute to the Prophet. For the yellow book format, although the advancement of printing technology is currently evolving, the yellow book format, the prints are still the same as they used to be, that is, generally not bound or wrapped in leather covers and yellow paper. Because to maintain physical characteristics that generally contain symbolic meanings, which seem to be more classical. The yellow book composed by earlier scholars or Islamic literature has not changed in terms of its contents, since the author or scholar who has been inhabited and his wisdom is no doubt, the scholars are the heirs of the Prophet, and so on. In addition, the yellow book functioned also by the boarding school as a reference in addressing all life challenges, as well as an arena of innovation to face the modern world.
\end{abstract}

Keywords: literature, islam, pesantren

\section{Pendahuluan}

\section{a. Latar Belakang}

Kehadiran pesantren di awal pertumbuhannya sudah tentu menampilkan suasana Islam ketika itu, baik dikawasan asalnya (Timur Tengah) maupun ketika menjejakkan kaki untuk pertama kali di wilayah Nusantara. Menurut Bawani, dkk (2011:46) di kawasan asal pekembangannya (Timur Tengah), pada saat itu Islam sudah tidak lagi berada di puncak kejayaannya, setelah Baghdad dan Spanyol jatuh ke tangan bangsa Mongol pada kurang lebiih abad XIII Masehi. Akibatnya, keunggulan di bidang sains dan peradaban yang pernah didominasi kaum muslim sebelum itu secara perlahan menjadi lenyap. Kaum muslim berganti menoleh dan kemudian tenggelam dalam tasawauf, seolah ingin terlepas dari keruwetan duniawi. Pada kondisi inilah 
Islam dalam pengertian massal, bukan individual orang per orang masuk ke berbagai daerah Nusantara, bersentuhan dengan adatistiadat dan tradisi budaya lokal yang bernapaskan Hindhu-Budha dan animisme, sehingga mau tidak mau akan terbawa pula hasil asimilasinya ke dalam wujud pesantren. Berdasarkan latar belakanng historis seperti itulah, secara umum pesantren sebagai lembaga pendidikan yang berorientasi pada ilmu keagamaan, khususnya fiqh, tasawuf, nahwu, sharraf dan sebagainya.

Bawani, dkk (2011:45) mengatakan bahwa pandangan kesejarahan menunjukkan bahwa kehadiran pesantren di negeri ini seiring dengan proses penyebaran agama Islam yang untuk pertama kalinya dilakukan atau dibawa oleh kepemimpinan para wali. Awalnya, pesantren merupakan pusat penyebaran Islam oleh para wali yang merupakan sambungan sistem zawiyah (sistem pembelajaran atau transmisi keilmuan yang mula-mula diselenggarakan di dalam masjid secara berkelompok berdasarkan diversivikasi aliran sehingga pada tataran selanjutnya mengkristal menjadi aliran-aliran pemikiran agama atau shcools of thougt) di India dan Timur Tengah. Hal ini berarti para wali itulah yang merintis berdirinya model lembaga pendidikan Islam tertua di indonesia yang bernama pesantren.

Selanjutnya Menurut De Graaf dan Th. G, Th. Pigeaud dalam Bawani, dkk (2011:46), para wali juga dikenal sebagai tokoh spiritual atau bahkan perancang skenario bagi munculnya kesultanan Islam diberbagai wilayah nusantara, maka dapat dibayangkan betapa penting dan strategisnya kedudukan pesantren ketika itu dalam percaturan puncak kekuasaan pemerintahan. sebagai contoh, sunan Giri dengan pesantrennya di puncak perbukitan yang berlokasi di bagian selatan kota Gresik, Jawa Timur, dikabarkan adalah figur di belakang layar bagi lahirnya kesultanan Islam Demak Bintoro di Jawa Tengah yang cukup terkenal itu. 
Alwi Syihab dalam Haedari, dkk (2004: 6), menegaskan bahwa Syaikh Maulana Malilk Ibrahim atau Sunan Gresik (w. $1419 \mathrm{H}$ ) merupakan orang pertama yang membangun pesantren sebagai tempat mendidik dan menggembleng para santri. Tujuannya agar para santri menjadi juru dakwah yang mahir sebelum mereka diterjunkan langsung di masyarakat luas. Gayung bersambut, usaha Syaikh pun berhasil menemukan momentum seiring dengan mulai runtuhnya singgasana kekuasaan Majapahit (1293-1478 M). Islam pun berkembang demikian pesat, khususnya di daerah-daerah pesisir yang berkebetulan menjadi pusat-pusat perdagangan antar daerah, bahkan antar negara.

Bahkan menurut Haedari, dkk (2004: 7) dari hasil penelusuran sejarah pula ditemukan sejumlah bukti kuat yang menunjukkan bahwa cikal bakal pendirian pesantren pada periode awal ini terdapat di daerah-daerah sepanjang pantai utara Jawa, seperti Giri (Gresik), Ampel Denta (Surabaya), Bonang (Tuban), Kudus, Lasem, Cirebon dan sebagainya. Kota-kota tersebut pada waktu itu merupakan kota kosmopolitas yang menjadi jalur penghubung perdagangan dunia, sekaligus sebagai tempat persinggahan para pedagang dan mubaligh Islam yang datang dari Jazirah Arabia seperti Hadramaut, Persia, Irak dan lain sebagainya. Hasil survei pemerintah Belanda yang pertama pada tahun $1819 \mathrm{M}$, juga menyebutkan bahwa lembaga pendidikan Islam tradisional terdapat dibeberapa kabupaten yang terletak di daerah pesisir, seperti Cirebon, Semarang, Kendal, Demak, Jepara, Surabaya, Gresik, Bawean, Sumenep, Pemekasan, dan Besuki.

Muhtarom (2005: 106-108) menyatakan bahwa fungsi pondok pesantren pada awalnya hanya sebagai sarana Islamisasi yang memadukan tiga unsur yakni, ibadah untuk menanamkan iman, tablig untuk menyebarkan Islam, dan ilmu serta amal untuk mewujudkan kegiatan sehari-hari dalam kehidupan 
bermasyarakat. Melihat fungsi pondok pesantren yang begitu kuat dalam mengembangkan Islam, pemerintah belanda yang pada waktu itu menguasai Mataram merasa khawatir. Kekhawatiran terletak pada perkembangan pondok pesantren tradisional dan Islam yang dicurigai sebagai kekuatan yang akan menggoyahkan kekuasaan belanda di Nusantara. Kyai yang mengajar ngaji dan memimpin pondok pesantren, secara sosiologis dilihatnya sebagai sosok yang mempunyai legitimasi dan karisma. Dengan mempunyai karisma tersebut, menimbulkan kataatan pengikut dengan pengorbanan habis-habisan.

Menurut Mastuki, dkk (2005: 3), ciri umum yang dapat diketahui adalah pesantren memiliki kultur khas yang berbeda dengan budaya sekitarnya. Beberapa peneliti menyebut sebagai sebuah sub kultur yang bersifat idiosyncratic, cara pengajarannya pun unik. Sang Kyai yang biasanya adalah pendiri sekaligus pemilik pesantren, membacakan manuskrip-manuskrip keagamaan klasik berbahasa arab yang dikenal dengan sebutan "kitab kuning". Sementara para santri mendengarkan sambil memberi catatan (ngesahi, jawa) pada kitab yang sedang dibaca. Metode ini disebut bandongan atau layanan kolektif (collektive learning process). Selain itu, para santri juga ditugaskan membaca kitab, sementara Kyai atau ustadz yang sudah mumpuni menyimak sambil mengoreksi dan mengevaluasi bacaan dan performance seorang santri. Metode ini dikenal dengan istilah sorogan atau layanan individual (individual learning process). Kegiatan belajar mengajar di atas berlangsung tanpa penjenjangan kelas dan kurikulum yang ketat, dan biasanya dengan memisahkan jenis kelamin siswa.

Adapun yang dimasud dengan "kitab kuning" merupakan kitab-kitab tradisional yang berisi pelajaran-pelajaran agama Islam yang diajarkan pada setiap pondok pesantren, yaitu yang dikatakan kitab kuning meliputi kitab Tauhid, Hadits, Tafsir, 
Sejarah, Fiqih, Nahwu, Sharraf, Ushul Fiqih, Tasawuf, Balaghah dan lainnya. Kitab tersebut dikenal juga dengan kitab "gundul, karena tidak memiliki harakat (tanda baca). Disebut kitab kuning dikarenakan memang kitab-kitab tersebut telah lama dimakan usia sehingga warna kertas berubah menjadi kuning. Namun kitab-kitab ini sebagian tetap diproduksi menggunakan kertas berwarna kuning. Walaupun ada juga yang dicetak menggunakan kertas berwarna putih. Kitab kuning merupakan faktor penting yaitu selain sebagai pedoman tatacara keberagamaan, kitab kuning difungsikan juga oleh kalangan pesantren sebagai referensi dalam mensikapi segala tantangan hidup. (http://repository.usu.ac.id/bitstream).

\section{b. Rumusan Maslah}

1. Bagaimanakah karakteristik pesantren?

2. Apa sajakah literatur-literatur keislaman yang ada di pesantren?

3. Bagaimana format literatur keislaman dalam konteks pesantren?

4. Apakah literatur keislaman (kitab kuning) yang dikarang oleh ulama terdahulu mengalami perubahan pada saat ini?

\section{c. Tujuan Pembahasan}

1. Untuk mengetahui karakteristik pesantren.

2. Untuk mengetahui literatur-literatur keislaman yang ada di pesantren.

3. Untuk mengetahui format literatur keislaman dalam konteks pesantren.

4. Untuk mengetahui apakah literatur keislaman (kitab kuning) yang dikarang oleh ulama terdahulu mengalami perubahan atau tidak pada saat ini.

\section{Pembahasan}

\section{a. Pengertian Pesantren}


Menurut Zamakhsyari Dhofier dalam Nasir (2005:81), pesantren berasal dari kata santri, yang dengan awalan pe di depan dan akhiran an berarti "tempat tinggal para santri". Lebih lanjut beliau mengutip dari pendapat profesor Johns dalam "Islam in South Asia" bahwa istilah santri berasal dari bahasa Tamil, yang berarti "guru ngaji". Sedangkan menurut Sudjoko dalam Bawani (2011:89), pesantren ialah lembaga pendidikan dan pengajaran agama Islam, umumnya dengan cara non klasikal, di mana seorang Kyai mengajarkan ilmu agama Islam kepada santri-santri berdasarkan kitab-kitab yang ditulis dalam bahasa Arab oleh ulama abad pertengahan, dan para santri biasanya tinggal di pondok (asrama) dalam pesantren tersebut.

Dari segi terminologis pesantren menurut Mastuhu (1994:55), merupakan sebuah lembaga pendidikan Islam tradisional untuk mempelajari, memahami, menghayati dan mengamalkan ajaran Islam dengan menekankan pentingnya moral keagamaan sebagai pedoman perilaku sehari-hari. Sedangkan menuru Barton (2006:26), pesantren adalah sekolah agama Islam yang menyediakan asrama bagi murid-muridnya yang dipimpin oleh seorang ulama atau Kyai. Secara teknis menurut Wahid (1995:267) pesantren ialah "tempat tinggal santri" pengertian tersebut menunjukkan ciri pesantren yang paling tinggi, yaitu sebuah lingkungan pendidikan yang sepenuhnya total. Pesantren mirip dengan akademi militer atau biara dalam hal pengalaman dan kemungkinannya untuk sebuah totalitas dibandingkan dengan lingkungan pendidikan parsial yang ditawarkan oleh sistem sekolah umum yang berlaku sebagai "struktur pendidikan secara umum" bagi bangsa, pesantren merupakan sebuah kultur yang unik.

\section{b. Eelemen-Elemen dan Karakteristik Pesantren}

1. Elemen-Elemen Pesantren 
Hampir dapat dipastikan, lahirnya suatu pesantren berawal dari beberapa elemen dasar yang selalu ada di dalamnya. Menurut Haedani, dkk (2004:25-26), ada lima elemen pesantren antara satu dengan lainnya tidak dapat dipisahkan. Kelima elemen tersebut meliputi Kyai (pengasuh pondok pesantren), Santri (siswa atau murid yang belajar di pesantren), Pondok (tempat tinggal (asrama) para santri), Masjid dan Pengajaran Kitab-Kitab Islam Klasik, atau yang sering disebut dengan kitab kuning. Meski demikian, bukan berarti elemen-elemen yang lain tidak menjadi bagian penting dalam sebuah lembaga pendidikan pesantren. Sebaliknya, perkembangan dan kemajuan peradaban telah mendorong pesantren untuk mengadopsi ragam elemen bagi teroptimalisasikannya pelaksanaan pendidikan pesantren.

2. Karakteristik Pesantren

Potret pesantren dapat dilihat berbagai segi sistem pendidikan pesantren secara menyeluruh, yang meliputi:

a. Materi Pelajaran dan Metode Pengajaran

Mastuki, dkk (2005:89), menyatakan bahwa pada dasarnya pesantren hanya mengajarkan ilmu dengan sumber kajian atau mata pelajarannya kitab-kitab yang ditulis atau berbahasa Arab. Sumber-sumber tersebut mencakup Al-Quran beserta Tajwid dan Tafsirnya, 'Aqaid dan Ilmu Kalam, Fiqh dan Ushul Fiqh, Hadits dan Musthalahah Al-Hadits, bahasa Arab dengan seperangkat ilmu alatnya, seperti Nahwu, Sharaf, Bayan, Ma'ani, Badi' dan 'Arudh, Tarikh, Manthiq, dan Tasawuf, kajian-kajian tersebut biasa disebut sebagai kitab kuning.

Adapun metode yang lazim digunakan dalam pendidikan pesantren menurut Mastuki, dkk (2005:89), 
adalah wetonan, sorogan, dan hafalan. Metode wetonan merupakan metode kuliah di mana para santri mengikuti pelajaran dengan duduk di sekeliling Kyai yang menerangkan pelajaran. Santri menyimak kitab masingmasing dan mencatat jika perlu. Metode sorogan sedikit berbeda dari metode wetonan di mana santri menghadap guru satu persatu dengan membawa kitab yang dipelajari sendiri. Kyai membacakan dan menerjemahkan kalimat demi kalimat. Kemudian menerangkan maksudnya, atau Kyai cukup menunjukkan cara membaca yang benar, tergantung materi yang diajukan dan kemampuan santri. Adapun metode hafalan berlangsung di mana santri menghafal teks atau kalimat tertentu dari kitab yang dipelajarinya. Materi hafalan biasanya dalam bentuk syair atau nazham. Sebagai pelengkap metode hafalan sangat efektif untuk memelihara daya ingat (memorizing) santri terhadap materi yang dipelajari, karena dapat dilakukan baik di dalam maupun di luar kelas.

b. Fungsi Pesantren, menurut Azra dalam Mastuki, dkk (2005:90), ada 3, yaitu, transmisi dan transfer ilmu-ilmu Islam, pemeliharaan tradisi Islam, dan reproduksi ulama.

c. Prinsip-prinsip pendikan pesantren menurut Hasyim (1995:93), yaitu keikhlasan, kesederhanaan, kemandirian, bebas, ukhuwah islamiyah.

d. Sarana dan Tujuan Pesantren

Mastuki, dkk (2005:92), menyatakan bahwa dengan menyadarkan diri kepada Allah SWT, para Kyai pesantren memulai pendidikan dengan modal niat ikhlas dakwah untuk menegakan kalimat-Nya, didukung dengan sarana prasarana sederhana dan terbatas. 
Keterbatasan sarana dan prasarana ini, ternyata tidak menyurutkan para Kyai dan santri untuk melaksanakan program-program pesantren yang telah dicanangkan. Mereka seakan sepakat bahwa pesantren adalah tempat untuk melatih diri (riyadloh) dengan penuh keprihatinan. Yang penting semua itu tidak menghalangi mereka menuntut ilmu.

e. Ciri-Ciri Pendidikan Pesantren

Adapun ciri-ciri pendidikan pesantren menurut Mastuki, dkk (2005:93), dapat diidentifikasikan sebagai berikut:

1) Adanya hubungan antara santri dengan Kyai-Nya, di mana hubungan santri dan Kyai itu ada jarak yang sifatnya vertikal bukan horizontal.

2) Kepatuhan santri kepada Kyai.

3) Hidup hemat dan sederhana benar-benar diwujudkan dalam lingkungan pesantren.

4) Kemandirian amat terasa di pesantren.

5) Jiwa tolong-menolong dan suasana persaudaraan (ukhuwah islamiyah) sangat mewarnai pergaulan di pesantren.

6) Disiplin sangat dianjurkan, untuk menjaga kedisiplinan ini pesantren biasanya memberikan sanksi-sanksi edukatif.

7) Keprihatinan untuk mencapai tujuan mulia. Hal ini sebagai akibat kebiasaan puasa sunat, zikir, i'tikaf, shalat tahajud, dan bentuk-bentuk riyadhoh lainnya atau menauladani Kyai-Nya yang menonjolkan sikap zuhud.

8) Pemberian ijazah, yaitu pencantuman nama dalam satu daftar rantai pengalihan pengetahuan yang diberikan kepada santri-santri yang berprestasi. 


\section{c. Pengertian Literatur}

Menurut Lasa (2009:191), Kata literatur berasal dari kata literature (bahasa latin) berarti huruf/letters. Pada mulanya literatur diartikan dengan kesusasteraan dan kepustakaan, namun dalam perkembangan selanjutnya literatur berarti semua catatan dan rekaman pemikiran intelektual dan artistik manusia sejak dulu sampai sekarang. Hasil ciptaan manusia itu beralih dari generasi ke generasi dengan cara lisan maupun tertulis.

Literatur adalah bahan atau sumber ilmiah yang biasa digunakan untuk membuat suatu karya tulis atau pun kegiatan ilmiah lainnya. Literatur ini mirip dengan daftar pustaka atau referensi. Jika anda kebingungan untuk mencari materi dari suatu ilmu pengetahuan, maka anda akan mencari referensi ke sumber lain. Referensi ke sumber lain itulah yang dinamakan literatur. Bentuk dari literatur bisa berupa softcopy atau hardcopy. Yang dimaksud softcopy adalah materi atau referensi yang berbentuk data komputer, sedangkan hardcopy adalah materi atau referensi yang berbentuk buku dan telah tercetak di kertas. (http:/ / kumpulanliteratur.blogspot.co.id/2011/11/).

Di antara para intelektual muslim yang belajar tentang keislaman di kawasan timur tengah yang datang dari Indonesia. Dalam sebuah tabloid yang berjudul "Pramuka Santri yang Semakin Menggigit" (2009:16), dikatakan bahwa harus diakui, keistimewaan belajar di Timur Tengah yang utama adalah adanya literature keislaman klasik (turats) yang bisa dikatakan lebih dari sekedar cukup. Di mana literaturliteratur ini cukup banyak membantu untuk memahami Islam secara lebih utuh dan komprehensif. Dalam konteks ini, pesantren sebagai lembaga pendidikan Islam yang banyak mempunyai literatur keislaman klasik menempati posisi yang 
sangat strategis. Terutama jika dibandingkan dengan lembaga pendidikan Islam lain di luar pesantren seperti yang banyak berkembang pada saat ini.

Nuha (2010: 18) menyatakan bahwa pesantren yang merupakan lembaga keagamaan yang identik dengan tafaqquh fid din memperdalam ilmu agama. Pengembangan yang dilakukan pesantren tidak boleh meninggalkan identitasnya sebagai lembaga tafaqqu fid din. Konsentrasi utama pesantren tetap pada jalur kulturalnya, yaitu pendidikan agama dengan dua sasaran (transfer pengetahuan dan transfer moral) dan pengabdian sosial dengan tulus.

\section{d. Literatur (Kepustakaan) Keislaman dalam Konteks}

\section{Pesantren}

Secara universal literatur keislaman yang ada di pesantren yang dipelihara dan diwariskan dari generasi ke generasi yang secara langsung berkaitan dengan ilmu-ilmu agama sebagaimana diwariskan kepada masyarakat Islam oleh imam-imam besar di masa lalu yang disebut dengan "kitab kuning" adalah untuk menyediakan akses bagi para santri, bukan hanya menuju warisan yurisprudensi atau jalan terang menuju kesadaran esoteris tertinggi tentang status kehambaan manusia (ubudiyah) di mata Tuhan, akan tetapi juga untuk mengindikasikan peranan dalam kehidupan dan kesentausaan masyarakat di masa yang akan datang.

Literatur atau buku yang digunakan di dalam dan di sekitar pesantren yaitu buku yang disebut dengan kitab kuning. Van den Berg dalam Martin Van Bruinessen (1995: 131), menyusun sebuah daftar buku-buku teks utama yang dipelajari di pesantren pada masanya (1886) berdasarkan wawancara dengan Kyai. Van den Berg menyebutkan lima puluh (50) judul buku dan memberikan informasi umum tentang masing-masing buku tersebut, dengan memberikan 
ringkasan singkat dari buku-buku yang lebih penting. Kebanyakan dari buku tersebut masih dicetak ulang dan dipergunakan di Indonesia, Singapura, Malaysia hingga sekarang, tetapi banyak karya lain yang juga dipakai di samping buku-buku tersebut. Koleksi yang ada sekarang mencakup sekitar sembilan ratus (900) judul buku yang berbeda-beda yang kebanyakan dipakai sebagai buku-buku teks.

Van den Berg dalam Martin Van Bruinessen (1995: 134), menyatakan berdasarkan statistik dari sekitar 900 karya yang berbeda-beda, hampir 500 atau lebih dari separuh ditulis atau diterjemahkan oleh ulama Asia Tenggara. Kebanyakan para ulama tersebut menulis dalam bahasa Arab, hampir 100 judul atau sekitar 10\%, merupakan karya-karya berbahasa Arab oleh orang-orang Asia Tenggara (orang-orang Arab yang menetap di wilayah tersebut). Jika kita menghitung kitab terjemahan sebagai karya terpisah, koleksi tersebut dapat dikatakan berisi, yaitu sebagai berikut:

Tabel 1

\begin{tabular}{|l|l|c|}
\hline 1 & kitar 500 karya dalam Bahasa Arab & $55 \%$ \\
\hline 2 & kitar 200 karya dalam Bahasa Melayu & $22 \%$ \\
\hline 3 & kitar 120 karya dalam Bahasa Jawa & $13 \%$ \\
\hline 4 & kitar 35 karya dalam Bahasa Sunda & $4 \%$ \\
\hline 5 & kitar 25 karya dalam Bahasa Madura & $2.5 \%$ \\
\hline 6 & kitar 20 karya dalam Bahasa Indonesia & $2 \%$ \\
\hline 7 & karya dalam Bahasa Aceh & $0,5 \%$ \\
\hline
\end{tabular}

Karya-karya tersebut dapat diklasifikasikan ke dalam beberapa ketegori pokok pembahasannya, yaitu:

Tabel 2

\begin{tabular}{|l|l|c|}
\hline 1 & qh & $20 \%$ \\
\hline 2 & kktrin (Akidah/Ushuluddin) & $17 \%$ \\
\hline
\end{tabular}




\begin{tabular}{|l|l|c|}
\hline 3 & $\begin{array}{l}\text { ta Bahasa Arab Tradisional (Nahu, Sharaf } \\
\text { \& Balaghah) }\end{array}$ & $12 \%$ \\
\hline 4 & Impulan Hadits & $8 \%$ \\
\hline 5 & sawuf dan Tarekat & $7 \%$ \\
\hline 6 & hlak & $6 \%$ \\
\hline 7 & Impulan Doa, Wirid, Mujarobat & $5 \%$ \\
\hline 8 & $\begin{array}{l}\text { shash Al-Anbiya, Maulid, Manaqib, dan } \\
\text { Sejenisnya. }\end{array}$ & $6 \%$ \\
\hline
\end{tabular}

Menjelang akhir abad 19 L.W.C. Van den Berg dalam Martin Van Bruinessen (1995: 29), mengunjugi sejumlah pesantren penting di Jawa dan Madura, dan menyusun daftar kitab-kitab berbahasa arab yang lazim dipelajari berdasarkan wawancara dengan Kyai. Disebutkan "Berbahasa Arab" menyiratkan bahwa karya-karya dalam bahasa lain (mungkin bahasa Jawa yang ditulis dalam huruf Arab, Jawa Pegon) juga digunakan. Van Den Berg, menjelaskan bahwa ada kesinambungan yang jelas dengan kitab-kitab terdahulu, dalam artian bahwa baik karya-karya pengantar yang dipakai maupun kitab bereputasi tinggi yang disebutkan ternyata sama. Kitab-kitab yang dipelajari yaitu seperti Kitab Fiqih, Kitab Tafsir (seperti Jalalain: Suyuthi dan Mahalli) serta Tafsir Baidhawi dan kumpulan Hadis Bukhari.

Berdasarkan hasil penelitian yang dilakukan oleh L.W.C. Van de Berg dalam Martin Van Bruinessen (1995: 149-168), terhadap literatur yang ada atau mengenai kepustakaan yang dipelajari di dalam dan di seputar pesantren, Van den Berg mendapatkan data judul-judul kitab yang umum dipakai, yang ditransliterasikan menurut cara yang lazim dipakai dalam bahasa Indonesia, yaitu bisa dilihat pada tabel-tabel yang ada di bawah ini:

Tabel 3 
Tata Bahasa Arab, Tajwid, Logika

\begin{tabular}{|c|c|c|c|c|c|c|}
\hline Daerah & umatera & Kalsel & Tabar & Tateng & Tatim & umlah \\
\hline Jumlah Pesantren & 4 & 3 & 9 & 12 & 18 & 46 \\
\hline \begin{tabular}{l}
\multicolumn{1}{c}{ Sharf } \\
1. Kailani/Syarah \\
Kailani \\
2. Maqshud/Syarah \\
Maqsud \\
3. Amtsilatut \\
Tashrifiyah \\
4. Bina'
\end{tabular} & $\begin{array}{l}2 \\
0 \\
0 \\
1\end{array}$ & $\begin{array}{l}1 \\
1 \\
0 \\
0\end{array}$ & $\begin{array}{l}7 \\
2 \\
0 \\
4\end{array}$ & $\begin{array}{l}0 \\
3 \\
3 \\
1\end{array}$ & $\begin{array}{l}4 \\
5 \\
4 \\
0\end{array}$ & $\begin{array}{l}14 \\
11 \\
7 \\
6\end{array}$ \\
\hline $\begin{array}{l}\text { Nahwu } \\
\text { 1. Jurumiyah/Syarah } \\
\text { Jurumiyah } \\
\text { 2. Imrithi/Sharah } \\
\text { Imrithi } \\
\text { 3. Mutamimmah } \\
\text { 4. Asymawi } \\
\text { 5. Alfiyah } \\
\text { 6. Ibnu Aqil } \\
\text { 7. Dahlan alfiyah } \\
\text { 8. Qathrun Nada } \\
\text { 9. Awamil } \\
\text { 10. Qawaidul Irab } \\
\text { 11. Nahwu Wahdhih } \\
\text { 12. Qawaidullughat }\end{array}$ & $\begin{array}{l}3 \\
0 \\
0 \\
0 \\
0 \\
1 \\
0 \\
3 \\
1 \\
0 \\
0 \\
0\end{array}$ & $\begin{array}{l}1 \\
0 \\
1 \\
0 \\
0 \\
0 \\
0 \\
1 \\
0 \\
0 \\
0 \\
0\end{array}$ & $\begin{array}{l}8 \\
3 \\
5 \\
1 \\
8 \\
0 \\
1 \\
0 \\
1 \\
0 \\
0 \\
0\end{array}$ & $\begin{array}{c}9 \\
\\
6 \\
0 \\
0 \\
11 \\
3 \\
0 \\
0 \\
1 \\
1 \\
2 \\
2\end{array}$ & $\begin{array}{c}16 \\
\\
12 \\
7 \\
2 \\
11 \\
10 \\
3 \\
0 \\
1 \\
2 \\
3 \\
2\end{array}$ & $\begin{array}{c}37 \\
\\
21 \\
13 \\
3 \\
30 \\
14 \\
4 \\
4 \\
4 \\
3 \\
5 \\
4\end{array}$ \\
\hline $\begin{array}{l}\quad \text { Balaghah } \\
\text { 1. Jauharul Maknum } \\
\text { 2. Uqudul Juman }\end{array}$ & $\begin{array}{l}2 \\
0\end{array}$ & $\begin{array}{l}0 \\
0\end{array}$ & $\begin{array}{l}4 \\
3\end{array}$ & $\begin{array}{l}5 \\
0\end{array}$ & $\begin{array}{l}7 \\
4\end{array}$ & $\begin{array}{c}18 \\
7\end{array}$ \\
\hline $\begin{array}{l}\text { Tajwid } \\
\text { 1. Tuhfatul Athfal } \\
\text { 2. Hidayatus Shiban }\end{array}$ & $\begin{array}{l}0 \\
0\end{array}$ & $\begin{array}{l}0 \\
0\end{array}$ & $\begin{array}{l}1 \\
0\end{array}$ & $\begin{array}{l}1 \\
1\end{array}$ & $\begin{array}{l}4 \\
4\end{array}$ & $\begin{array}{l}6 \\
5\end{array}$ \\
\hline $\begin{array}{l}\text { Manthiq } \\
\text { 1. Sullamul Munauraq } \\
\text { 2. Idhabul Mubham }\end{array}$ & $\begin{array}{l}1 \\
2\end{array}$ & $\begin{array}{l}0 \\
0\end{array}$ & $\begin{array}{l}3 \\
1\end{array}$ & $\begin{array}{l}1 \\
1\end{array}$ & $\begin{array}{l}5 \\
3\end{array}$ & $\begin{array}{c}10 \\
7\end{array}$ \\
\hline
\end{tabular}

Tabel 4

Fiqh dan Ushul Fiqh

\begin{tabular}{|c|c|c|c|c|c|c|}
\hline Daerah & Amatera & kalsel & abar & lateng & latim & umlah \\
\hline Jumlah Pesantren & 4 & 3 & 9 & 12 & 18 & 46 \\
\hline $\begin{array}{c}\text { Fiqh } \\
\text { 1. Fathul Mu'in }\end{array}$ & 2 & 1 & 7 & 6 & 16 & 32 \\
\hline
\end{tabular}




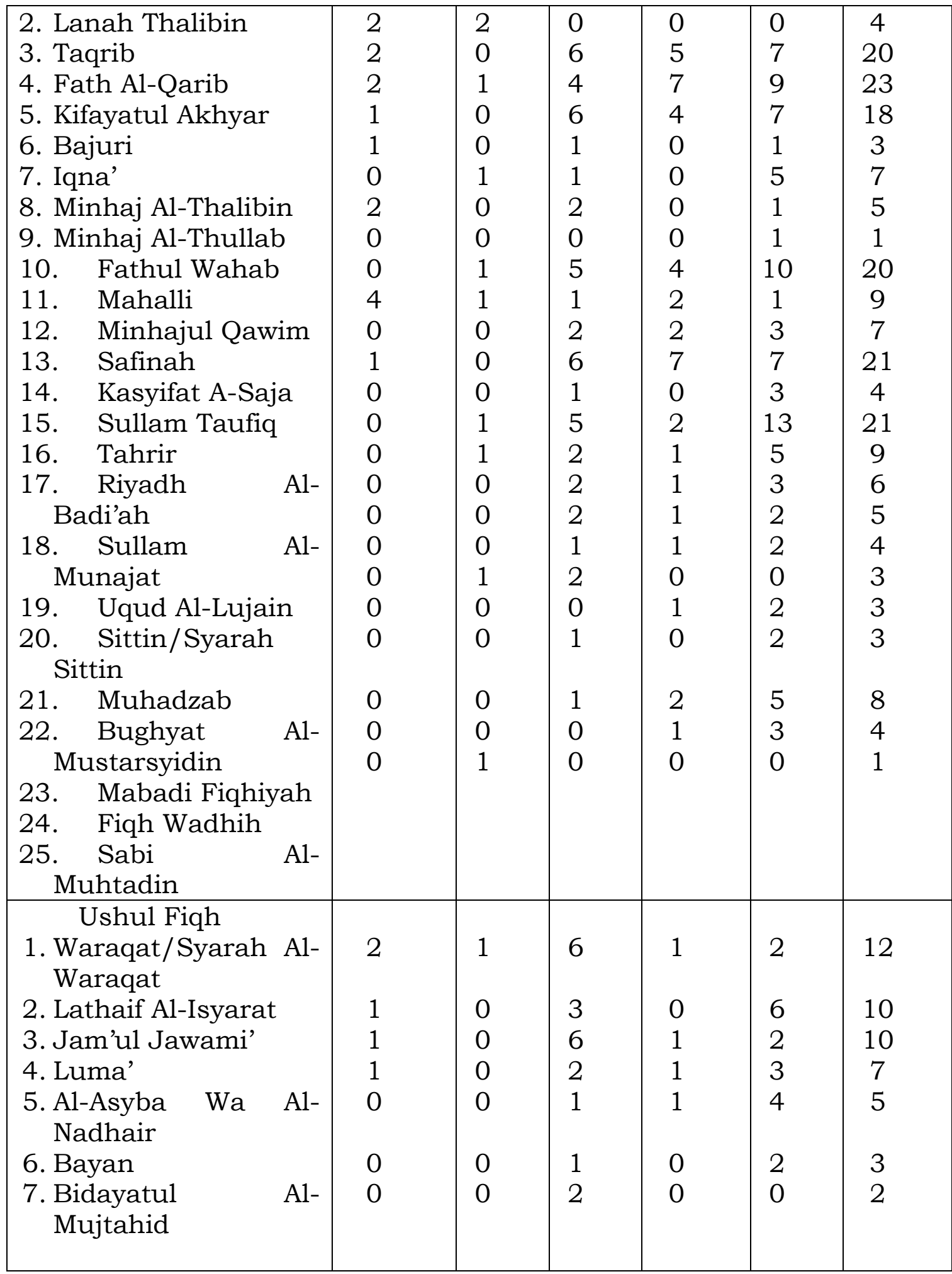

Tabel 5

Akidah (Ushuluddin, Tauhid)

\begin{tabular}{|l|l|l|l|l|l|l|}
\hline \multicolumn{1}{|c|}{ Daerah } & umatera & lalsel & labar & lateng & latim & umlah \\
\hline Jumlah Pesantren & 4 & 3 & 9 & 12 & 18 & 46 \\
\hline uhid & & & & & & \\
\hline
\end{tabular}




\begin{tabular}{|l|l|l|l|l|l|c|} 
1. Ummul Barahin & 2 & 0 & 2 & 0 & 1 & 5 \\
2. Sanusi & 2 & 0 & 3 & 3 & 3 & 11 \\
3. Dasuqi & 0 & 1 & 1 & 0 & 5 & 7 \\
4. Syarqawi & 1 & 1 & 0 & 0 & 1 & 3 \\
5. Kifayatul Awam & 4 & 1 & 2 & 2 & 8 & 17 \\
6. Tijanud Durari & 1 & 0 & 5 & 2 & 3 & 11 \\
7. Aqidatul Awam & 0 & 0 & 0 & 4 & 9 & 13 \\
8. Nuruzh Zhulam & 0 & 1 & 1 & 0 & 1 & 3 \\
9. Jauharud Tauhid & 1 & 0 & 3 & 2 & 1 & 7 \\
10. Tuhfatul Murid & 0 & 1 & 0 & 0 & 2 & 3 \\
11. Fathul Majid & 2 & 1 & 1 & 2 & 2 & 8 \\
12. Jawahirul & 0 & 0 & 1 & 3 & 5 & 9 \\
$\quad$ Kalamiyah & 0 & 0 & 1 & 5 & 2 & 8 \\
13. Husnul & 1 & 0 & 0 & 1 & 2 & 4 \\
$\quad$ Hamidiyah & & & & & \\
14. Aqidatul & & & & & \\
$\quad$ Islamiyah & & & & & \\
\hline$\quad$
\end{tabular}

Tabel 6

Tafsir al-Quran

\begin{tabular}{|l|c|c|c|c|c|c|}
\hline \multicolumn{1}{|c|}{ Daerah } & Mmatera & lalsel & labar & lateng & latim & umlah \\
\hline Jumlah Pesantren & 4 & 3 & 9 & 12 & 18 & 46 \\
\hline$\quad$ Tafsir & & & & & & \\
1. Jalalain & 4 & 1 & 9 & 9 & 16 & 39 \\
2. Tafsirul Munir & 0 & 1 & 3 & 2 & 5 & 11 \\
3. Tafsir Ibn Katsir & 1 & 0 & 3 & 0 & 3 & 7 \\
4. Tafsir Baidhawi & 1 & 0 & 1 & 2 & 0 & 4 \\
5. Jamiul Bayan & 0 & 0 & 2 & 0 & 0 & 3 \\
$\quad$ Thabari) & 0 & 0 & 2 & 1 & 0 & 3 \\
6. Maraghi & 0 & 0 & 2 & 0 & 1 & 3 \\
7. Tafsirul Manar & 0 & 0 & 0 & 1 & 1 & 2 \\
8. Tafsir Dep. Agama & & & & & & \\
\hline$\quad$ 'Ilm Tafsir & & & & & & \\
1. Itqan & 0 & 0 & 2 & 0 & 1 & 3 \\
2. Itmamud Dirayah & 0 & 0 & 0 & 0 & 2 & 2 \\
\hline
\end{tabular}

Tabel 7

Hadits dan Ilmu Hadits

\begin{tabular}{|l|c|c|c|c|c|c|}
\hline \multicolumn{1}{|c|}{ Daerah } & umatera & lalsel & labar & lateng & latim & umlah \\
\hline Jumlah Pesantren & 4 & 3 & 9 & 12 & 18 & 46 \\
\hline Hadits & & & & & & \\
1. Bulughul Maram & 1 & 0 & 6 & 5 & 12 & 24 \\
2. Subulus Salam & 1 & 1 & 0 & 0 & 1 & 3 \\
3. Riyadhus Shalihin & 1 & 0 & 7 & 6 & 9 & 23 \\
4. Shahih Bukhari & 2 & 1 & 6 & 7 & 5 & 21 \\
\hline
\end{tabular}




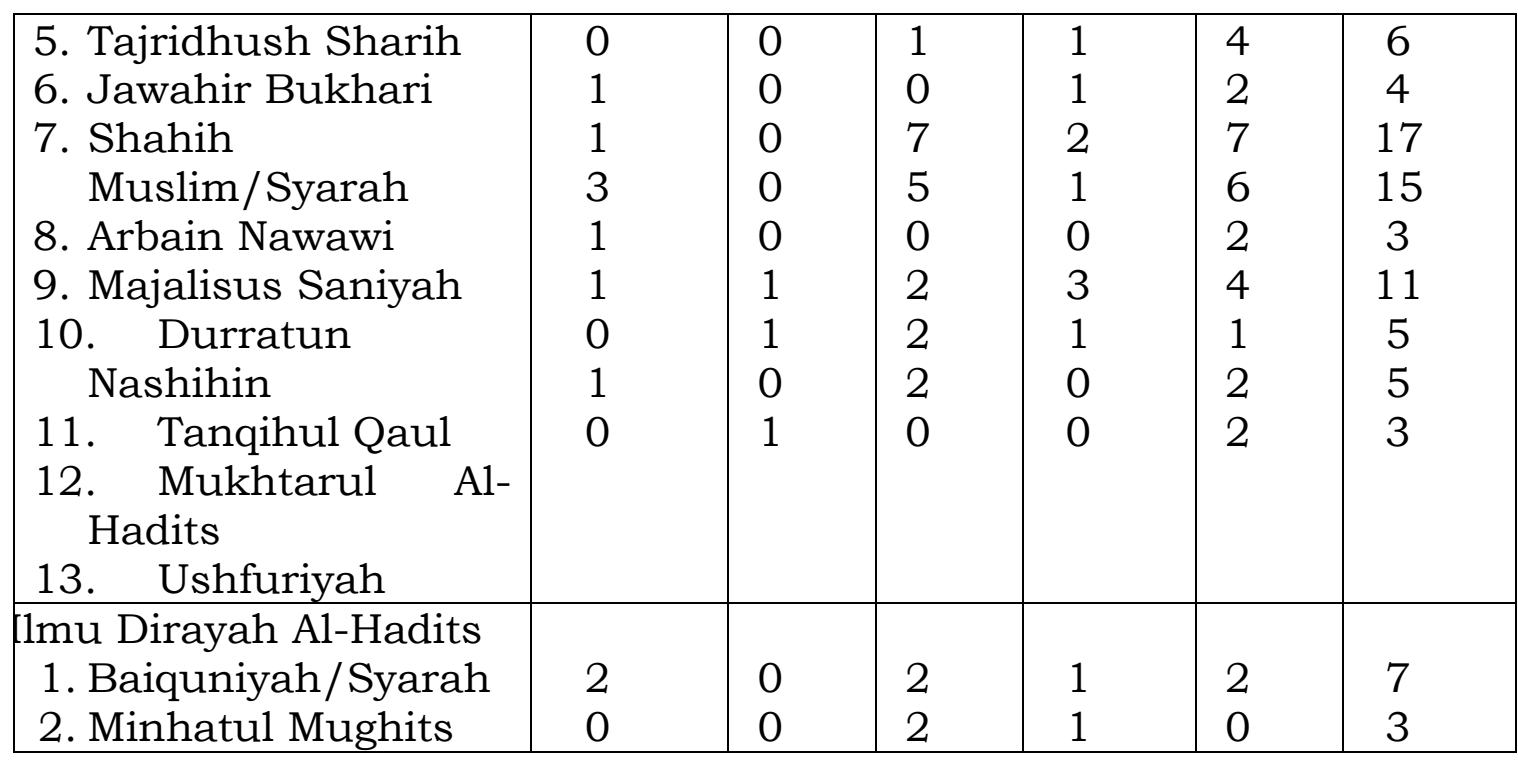

Tabel 8

Akhlak dan Tasawuf

\begin{tabular}{|l|l|l|l|l|l|l|}
\hline \multicolumn{1}{|c|}{ Daerah } & amatera & lalsel & abar & lateng & atim & umlah \\
\hline Jumlah Pesantren & 4 & 3 & 9 & 12 & 18 & 46 \\
\hline$\quad$ Akhlak & & & & & & \\
1. Talimul Mutaalim & 0 & 1 & 5 & 4 & 9 & 19 \\
2. Wasaya & 0 & 0 & 1 & 6 & 2 & 9 \\
3. Akhlak Lil Banat & 0 & 0 & 1 & 1 & 2 & 4 \\
4. Akhlak Lil Banin & 0 & 0 & 1 & 1 & 1 & 3 \\
5. Irsyadul Ibad & 0 & 1 & 1 & 0 & 5 & 7 \\
6. Nashaihul Ibad & 0 & 0 & 2 & 0 & 4 & 6 \\
\hline shawuf & & & & & & \\
1. Ihya Ulumuddin & 1 & 2 & 4 & 5 & 12 & 24 \\
2. Sairus Salikin & 1 & 1 & 1 & 0 & 0 & 3 \\
3. Bidayatul Hidayah & 0 & 0 & 2 & 2 & 8 & 12 \\
4. Maraqil Ubudiyah & 0 & 1 & 0 & 0 & 1 & 2 \\
5. Hidayatus Salikin & 1 & 0 & 1 & 0 & 0 & 2 \\
6. Minhajul Abidin & 0 & 3 & 3 & 1 & 3 & 10 \\
7. Sirajut Thalibin & 0 & 2 & 1 & 0 & 0 & 3 \\
8. Hikam/Syarah & 2 & 0 & 1 & 0 & 6 & 9 \\
$\quad$ Hikam & 0 & 0 & 0 & 1 & 4 & 5 \\
9. Hidayatul Adzkiya & 0 & 1 & 0 & 0 & 1 & 2 \\
10. Kifayatul Atqiya' & 0 & 1 & 1 & 0 & 4 & 6 \\
11. Risalatul & 0 & 0 & 1 & 0 & 3 & 4 \\
$\quad$ Muawanah & 0 & 1 & 1 & 0 & 1 & 3 \\
12. Nashaihud & & & & & & \\
$\quad$ Diniyah $\quad$ Adzkar & & & & & & \\
13. & & & & & & \\
$\quad \quad$
\end{tabular}

Tabel 9 
Sejarah Hidup Nabi (Sirah) dan Karya Pennghormatan Untuk Nabi SAW.

\begin{tabular}{|l|c|c|c|c|c|c|}
\hline \multicolumn{1}{|c|}{ Daerah } & umatera & alsel & labar & lateng & latim & umlah \\
\hline Jumlah Pesantren & 4 & 3 & 9 & 12 & 18 & 46 \\
\hline $\begin{array}{l}\text { 1. Khulashah Nurul } \\
\text { Yaqin }\end{array}$ & 2 & 1 & 2 & 3 & 2 & 10 \\
2. Barzanji & 0 & 1 & 1 & 1 & 0 & 3 \\
3. Dardir & 0 & 1 & 1 & 0 & 1 & 3 \\
\hline
\end{tabular}

Senada dengan pendapat di atas, Hak (2015:193), juga mengemukakan bahwa literatur atau materi-materi pelajaran yang ada di pesantren berbasis "kitab kuning" yang merupakan karya para ulama abad pertengahan dalam bidang Aqidah, Syari'ah (Fiqh dan Ushul Fiqh), Akhlaq (Tasawuf), Nahwu-Sharaf (Kaedah Bahasa Arab), Tafsir, Hadist, Tarikh (Sejarah), Mantiq (Ilmu Logika), Fadhail Al-Amal (Keutamaan Amal-Amal) dan Lainnya. Selain Kitab Besar dalam berbagai bidangnya seperti AlUmm karya Imam Syafi'i dalam bidang Fiqh, Jam'ul Jawami' dalam bidang Ushul Fiqh dan Ihya U'lumuddin dalam Bidang Akhlaq Tasawuf, di pesantren sering dikaji kitab-kitab kecil dalam bidang yang berbeda pula, yang di ajarkan bagi pemula, seperti Jurumiah, Nasa'ih Al'ibad karya Tanbib Al-Ghafillin, Safinah An-Najah, Sulam At,Taufiq. Berikut adalah kitab-kitab yang biasa dikaji dan menjadi bagian dari kepustakaan pesantren.

\begin{tabular}{|c|c|c|}
\hline $\mathrm{o}$ & Kitab & $\begin{array}{c}\text { Bagian dari Nama-Nama Kitab yang } \\
\text { Dikaji }\end{array}$ \\
\hline & Kitab-Kitab Tafsir & $\begin{array}{ll}\text { - } & \text { Tafsir Al-Jalalain } \\
\text { - } & \text { Tafsir Ibnu Kathir } \\
\text { - } & \text { Tafsir al-Baidawi } \\
\text { - } & \text { Tafsir al-Maraghi } \\
\text { - } & \text { Tafsir al-Manar } \\
\text { - } & \text { Al-'Itqan fi 'Ulum al-Qur'an }\end{array}$ \\
\hline & Kitab-Kitab Hadist & $\begin{array}{ll}\text { - } & \text { Riyadh As-Shalihin } \\
\text { - } & \text { Fath al-Barry } \\
\end{array}$ \\
\hline & Kitab-Kitab & - $\quad$ Kifayah al-Awam \\
\hline
\end{tabular}




\begin{tabular}{|c|c|c|}
\hline & Aqidah & $\begin{array}{ll}\text { - } & \text { Matan as-Sanusi } \\
\text { - } & \text { Hududi }\end{array}$ \\
\hline & Kitab-Kitab Fiqh & $\begin{array}{ll}- & \text { Fath al-Qarib } \\
\text { - } & \text { Fath al-Mu'in } \\
\text { - } & \text { I'anah al-Thalibin } \\
- & \text { al-Mughni } \\
- & \text { Fath al-Wahab } \\
\text { - } & \text { al-Mahalli } \\
\text { - } & \text { Sullam al-Taufiq } \\
\text { - } & \text { Masa'il Sittin } \\
\text { - } & \text { Mukhtashar } \\
- & \text { al-Hawasyi al-Madaniyah } \\
- & \text { al-Risalah } \\
- & \text { Minhaj a-Qawim } \\
- & \text { al-Iqna } \\
- & \text { Tuhfat al-Habib } \\
- & \text { al-Muharrar } \\
- & \text { Minhaj al-Halibi }\end{array}$ \\
\hline & Fiqh Kitab-Kitab Ushul & $\begin{array}{ll}\text { - } & \text { al-Waraqat } \\
\text { - } & \text { Lathaif al-Isyarah } \\
\text { - } & \text { Ghayat al-Whusul } \\
\text { - } & \text { Jam'ul Jawami }\end{array}$ \\
\hline & $\begin{array}{l}\text { Kitab-Kitab } \\
\text { Akhlaq/Tasawuf }\end{array}$ & $\begin{array}{ll}- & \text { Tanbih Al-Ghafilin } \\
- & \text { Maraghi ‘Ubudiyah } \\
- & \text { Al-Ahkam } \\
\text { - } & \text { Ihya 'ulumuddin } \\
\end{array}$ \\
\hline & $\begin{array}{c}\text { Kitab-Kitab } \\
\text { Mengenai Nahwu Sharaf }\end{array}$ & $\begin{array}{ll}\text { - } & \text { Al-Jurumiah } \\
\text { - } & \text { Al-'Awamil } \\
\text { - } & \text { Al-Amrithi } \\
\text { - } & \text { Muthammimah } \\
\text { - } & \text { Al-fiyah Ibnu Malik } \\
\text { - } & \text { Khurdi } \\
\text { - } & \text { Matan Bina Salsa al-Makhdal } \\
\text { - } & \text { Al-Kailani } \\
\text { - } & \text { Unwan as-Shafr } \\
\text { - } & \text { Al-Mazhab dan Mi'rat al-Ahwah }\end{array}$ \\
\hline & $\begin{array}{l}\text { Kitab-Kitab } \\
\text { Mengenai Mantiq (Ilmu } \\
\text { Logika) }\end{array}$ & $\begin{array}{ll}- & \text { Matan As-Sullam } \\
- & \text { Izhar al-Mubham } \\
- & \text { Al-Sabban } \\
- & \text { Al-Syamsiah }\end{array}$ \\
\hline & $\begin{array}{c}\text { Kitab-Kitab } \\
\text { Mengenai Balaghah }\end{array}$ & $\begin{array}{ll}\text { - } & \text { Ilm al-Balaghah } \\
\text { - } & \text { al-Bayan } \\
\text { - } & \text { Jawahir al-Maknun }\end{array}$ \\
\hline 0 & Kitab Tarikh & - Khulashah Nurul Yaqin \\
\hline
\end{tabular}

\section{e. Format Umum Literatur Keislaman (Kitab Kuning)}


Kebanyakan kitab Arab klasik yang dipelajari di pesantren adalah kitab komentar (syarh, Indonesia/Jawa, syarah) atau komentar atas komentar (hasyiyah) atas teks yang lebih tua (matan). Edisi cetakan dari karya-karya klasik ini biasanya menempatkan teks yang di-syarah atau di hasyiahi di cetak ditepi halamannya, sehingga keduanya dapat dipelajari sekaligus. Kebanyakan buku-buku teks dasar adalah manzhum, yakni ditulis dalam bentuk sajak-sajak berirama (nazhm), supaya mudah dihafal. Adapun karya manzhum yang paling panjang menurut Bruinessen (1995: 141), adalah kitab Alfiyah (sebuah teks tentang tata bahasa Arab, yang dinamakan demikian karena berjumlah seribu bait). Banyak para santri yang telah, dengan cara memandangnya dengan sabar, berusaha menghafal seluruh karya, bersamaan dengan seluruh teks lainnya. Beberapa syarah atas kitab manzhum ini biasanya menyertakan bait aslinya dalam teks (prosa) syarahnya, dan bukan menempatkan bait-bait sajak tersebut secara tersendiri di tepi halaman.

Selanjutnya Bruinessen (1995: 142), menyatakan bahwa sebagian kecil dari terjemahan baik berbahasa Jawa, Madura dan Sunda hanya berisi terjemahan sela baris yang ditulis mencong. Dengan tulisan lebih kecil, di bawah setiap kata teks Arab-nya yang dicetak tebal dan karena itu dijuluki jenggotan. Namun, seringkali ada tambahan terjemahan atau komentar yang lebih bebas yang biasanya dicetak di paruh bawah halaman tersebut. Adapun untuk format kitab klasik, Bruinessen (1995: 142), menyatakan bahwa format kitab klasik yang paling umum dipakai di pesantren sedikit lebih kecil dari kertas kuarto $(26 \mathrm{~cm})$ dan tidak dijilid. Lembaranlembaran (koras-koras) tidak dijilid dibungkus kulit sampul, sehingga para santri dapat membawa hanya satu halaman yang kebetulan sedang dipelajari saja. Ini adalah karakteristik 
fisik lain yang umumnya mengandung makna simbolik, yang tampak kelihatannya lebih klasik. Kitab yang ditulis oleh para pengarang modern, penerjemah atau pensyarah modern tidak pernah dibuat mengikuti format tersebut. Banyak pemakai kitab klasik yang sangat mengkaitkan karakteristik ini dengan kitab klasik, dan penerbit mengikuti saja selera konsumennya. Sebagian penerbit bahkan mencetak kitab di atas kertas berwarna kuning, karena tampaknya kitab berwarna kuning ini juga menjadi lebih klasik dipikiran para pemakainya.

Menurut Mas'udi (1986: 75), seiring dengan kemajuan teknologi percetakan, kitab kuning tidak harus selalu dicetak dengan kertas kuning. Akan tetapi, dicetak dengan kertas putih. Begitu pula dengan bacaannya, banyak dari kitab-kitab tersebut yang dilengkapi dengan tanda baca ata syakal (harokat) dengan tujuan untuk mempermudah orang-orang yang mempelajarinya walaupun mereka tidak begitu memahami ilmu nahwu dan sharraf yang diklaim sebagai dasar untuk memahami kandungan dari sebuah kitab.

Contoh Format Kitab Klasik

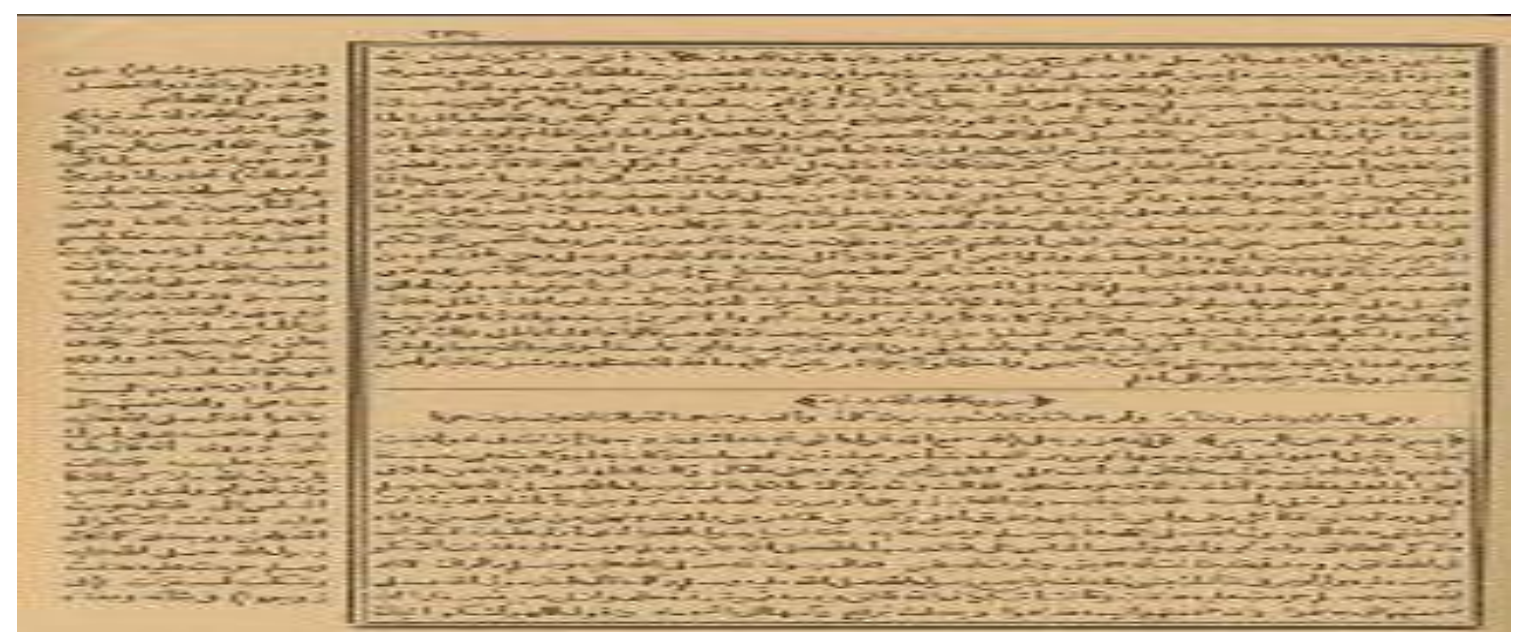




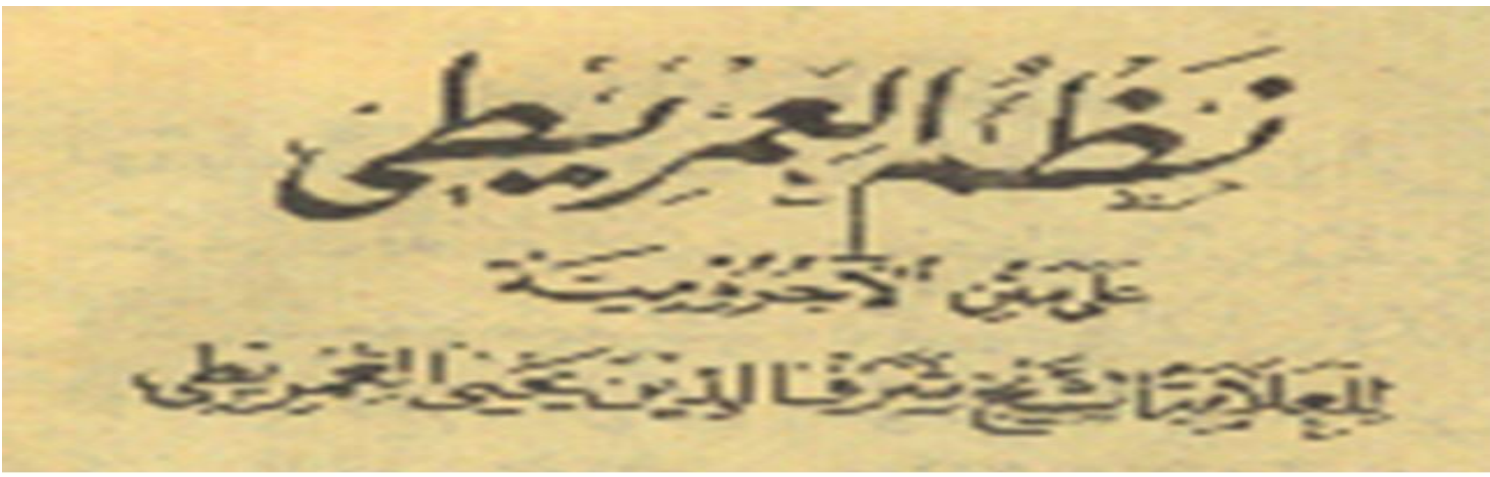

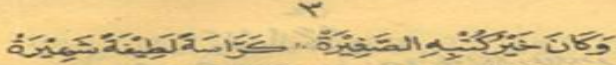

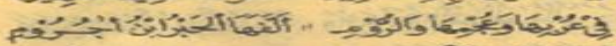

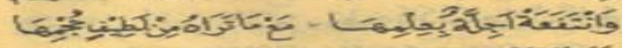

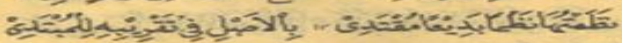

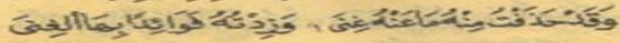

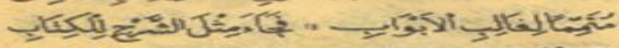

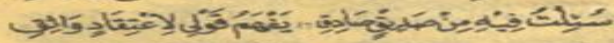

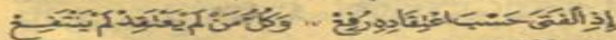

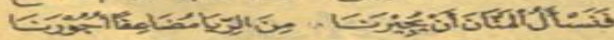

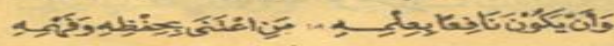

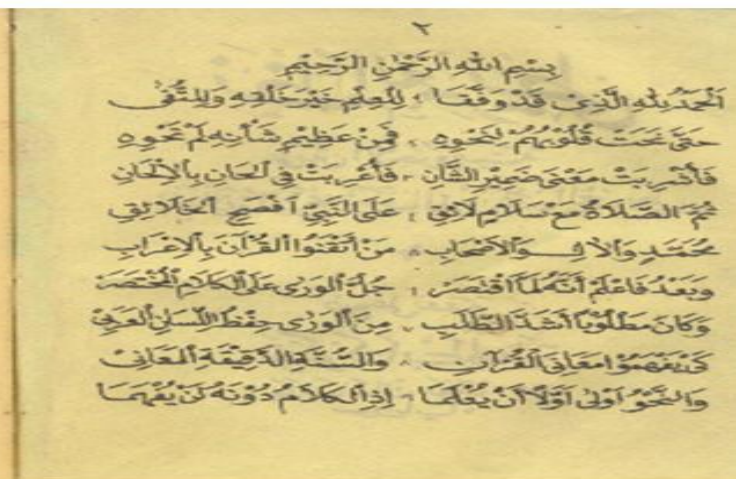

\section{f. Literatur Keislaman (Kitab Kuning) Tidak Mengalami Perubahan}

Menurut penulis, kitab kuning yang dikarang oleh ulama terdahulu atau literatur keislaman dalam konteks pesantren hingga saat ini tidak mengalami perubahan dari segi kandungan isinya, alasannya yaitu sebagai berikut:

1. Karena kitab kuning merupakan karya para ulama terdahulu, di mana tidak ada orang yang bisa menandinginya disebabkan ilmunya yang sudah mempuni dan kealimannya sudah tidak diragukan lagi. Dan sejak kelahiran Islam sampai dewasa ini, eksistensi ulama tetap diakui. Di dalam Al-Quran kata ulama disebut dua kalli, yaitu dalam surat asy-Syu'ara ayat 197 dan surat Fathir ayat 28. Sebagaimana artinya: "dan apakah tidak cukup menjadi bukti bagi mereka bahwa para ulama bani israil mengetahuinya..." (QS. Faathir. 28).

Ayat tersebut mengisyaratkan bahwa ulama merupakan hamba Allah yang beriman, bertaqwa, menguasai ilmu 
kauniyah dan tanziliyah, berpandangan hidup luas dan beribadah dengan landasan rasa takut kepada Allah SWT. Takut (khasyyah) merupakan sifat khusus ulama. Di mana khasyyah menurut Said bin Jubair dalam Hsubky (1995: 44), ialah rasa takut kepada Allah yang menghalangi seseorang dari perbuatan dosa.

Istilah Ulama oleh Ibnu Manzur dalam Nursukma (2004: 1), diartikan sebagai bentuk jamak dari kata benda (fail) bahasa arab 'alim, yang berasal dari kata kerja 'alima yang berarti "mengetahui atau berpengetahuan tentang sesuatu". Sedangkan 'alim menurut Mcdonald (1987: 994) adalah seorang yang memiliki atribut ilm (ilmu) sebagai suatu kekuatan yang berakar kuat dalam ilmu pengetahuan dan literatur. Lane (1984: 2138-2140), menjelaskan bahwa 'ilm (ilmu) adalah masdar taukid dari kata kerja 'alima yang berarti pengetahuan (knowledge) 'ilm berbeda dengan ma'rifah yang juga berarti "pengetahuan". Di dalam pengertian asli, istilah ma'rifah mengacu kepada pengetahuan dengan kualitas tertinggi yang kadang-kadang bisa diperoleh hanya secara intuitif, sementara 'ilm menunjuk kepada pengetahuan secara umum.

Selain itu, menurut Syekh Nawawi al-Bantani dalam Hsubky (1995: 46), ulama adalah orang-orang yang menguasai segala hukum syara' untuk menetapkan sahnya agama, baik penetapan sah i'tikad maupun amal syari'at lainnya. Selanjutnya Wahbah Az-Zuhaili berkata, secara naluri, ulama adalah orang-orang yang mampu menganalisa alam fenomena untuk kepentingan hidup dunia dan akhirat serta takut ancaman Allah jika terjerumus ke dalam kenistaan.

2. Ulama merupakan pewaris Nabi 
Sejumlah pengasuh pondok pesantren di indonesia menegaskan bahwa ulama adalah ahli waris nabi. KH. Muh Basri dalam dalam Hsubky (1995:64), mengatakan "ulama adalah orang yang bertakwa kepada Allah dan sanggup mengamalkan ilmunya, mengerti ilmu tafsir, ilmu hadits, dan tanggap terhadap masalah yang dihadapi umat pada zamannya. Selanjutnya Munawir Sjadzali dalam Hsubky (1995: 64), berpendapat, seorang ulama mempunyai peran sesuai dengan perkembangan zaman, di mana ulama memiliki tiga hal yaitu memiliki komitmen hanya dengan islam, integritas ilmunya tidak diragukan, dan loyal kepada umat dan bangsa.

3. Kitab kuning merupakan literatur keislaman yang dijadikan rujukan oleh masyarakat dalam mengatasi permasalahan hidup agar mendapatkan kebahagiaan di dunia dan akhirat. Dan fungsi kitab kuning merupakan suatu wacana yang mampu membuktikan kedudukan Al-Quran sebagai tibyanan li kulli syai' (penjelas bagi segala sesuatu) dalam kehidupan manusia yang selalu berubah. Sebuah kaidah itsbat al-tsawabit wa taghyir al-mutaghayyirat harus diterapkan, artinya ajaran Islam yang merupakan produk ijtihad selalu dimungkinkan untuk mengalami perubahan.

4. Karena melalui kitab kuning, kita bisa memahami pola pikir para ulama dalam mengembangkan ajaran Islam dan mengatasi permasalahan yang ada dengan mengedepankan kemaslahatan umat tanpa harus keluar dari jalur al-Quran dan al-Hadits yang merupakan sumber hukum ajaran islam. Karena ketika kita mengatasi suatu permaslahan pada saat ini, kita harus melakukan beberapa hal, yaitu dengan melihat kebelakang (memahami sejarah pemikiran dan sosial budaya), memahami permaslahan yang terjadi pada saat ini, dan memberikan proyeksi terhadap masa depan. 
5. Apabila kitab kuning mengalami perubahan, menurut K.H. Sahal Mahfudh (2004:xxxix), maka akan mengakibatkan terputusnya mata rantai sejarah dan budaya ilmiah yang sudah dibangun berabad-abad. Menutup kitab kuning berarti menutup jalur keilmuan yang menghubungkan tradisi keilmuan sekarang dengan tradisi keilmuan milik kita pada masa lalu.

6. Kitab kuning juga merupakan faktor penting, yaitu sebagai pedoman tatacara keberagamaan, kitab kuning difungsikan juga oleh kalangan pesantren sebagai referensi dalam mensikapi segala tantangan hidup.

7. Kitab kuning memang sebuah tradisi tapi sekaligus dengan itu dia juga arena inovasi, yang melalui dan mengacu padanya kalangan pesantren menanggapi dunia modern.

\section{Penutup}

\section{a. Kesimpulan}

Pesantren merupakan sebuah lembaga pendidikan Islam tradisional untuk mempelajari, memahami, menghayati dan mengamalkan ajaran Islam dengan menekankan pentingnya moral keagamaan sebagai pedoman perilaku sehari-hari. Ada lima elemen pesantren antara satu dengan lainnya tidak dapat dipisahkan. Kelima elemen tersebut meliputi Kyai, Santri, Pondok, Masjid dan Pengajaran Kitab-Kitab Islam Klasik, atau yang sering disebut dengan kitab kuning. Pesantren yang merupakan lembaga keagamaan yang identik dengan tafaqquh fid din memperdalam ilmu agama. Secara keseluruhan literatur keislaman yang ada di pesantren yang dipelihara dan diwariskan dari generasi ke generasi yang secara langsung berkaitan dengan ilmu-ilmu agama sebagaimana diwariskan kepada masyarakat Islam oleh imamimam besar di masa lalu yang disebut dengan "kitab kuning". Kitab-kitab tersebut meliputi teks yang sangat pendek sampai teks yang terdiri dari berjilid-jilid tebal mengenai Tata Bahasa Arab, 
Tajwid, Logika, Fiqh dan Ushul Fiqh, Akidah (Ushuluddin, Tauhid), Tafsir al-Quran, Hadits dan Ilmu Hadits, Akhlak dan Tasawuf, Sejarah Hidup Nabi (Sirah) dan Karya Penghormatan Untuk Nabi SAW. Secara umum, kitab yang diajarkan di pesantren baik di Jawa maupun di Madura adalah sama jenisnya, sampai saat ini.

Kitab kuning yang dikarang oleh ulama terdahulu atau literatur keislaman dalam konteks pesantren sampai saat ini tidak mengalami perubahan dari segi kandungan isinya, karena pengarang dari kitab te sudah tisebut sudah tidak diragukan lagi ilmunya, ulama merupakan pewaris Nabi, kitab kuning dijadikan rujukan oleh masyarakat dalam mengatasi permasalahan hidup di mana kitab kuning merupakan suatu wacana yang mampu membuktikan kedudukan Al-Quran sebagai tibyanan li kulli syai', melalui kitab kuning, kita bisa memahami pola pikir para ulama dalam mengembangkan ajaran Islam dan mengatasi permasalahan yang ada dengan mengedepankan kemaslahatan umat tanpa harus keluar dari jalur al-Quran dan al-Hadits, dengan kitab kuning maka mata rantai sejarah dan budaya ilmiah yang sudah dibangun berabad-abad tidak akan pernah terputus, kitab kuning difungsikan juga oleh kalangan pesantren sebagai referensi dalam mensikapi segala tantangan hidup, serta sebagai arena inovasi untuk menanggapi dunia modern.

\section{b. Saran}

Ada beberapa hal yang dapat penulis sarankan sebagai bagian penutup dari pembahasan penulis ini, yaitu:

1. Untuk semua lembaga Pondok Pesantren, diharapkan untuk selalu menerapkan, mengkaji lebih dalam lagi dan mempertahankan literatur keislaman (kitab kuning), sebagaimana fungsi dari awal pembentukan pondok pesantren tersebut, yaitu sebagai sarana islamisasi yang memadukan tiga unsur yakni, ibadah untuk menanamkan iman, tablig untuk menyebarkan Islam, dan ilmu serta amal 
untuk mewujudkan kegiatan sehari-hari dalam kehidupan bermasyarakat.

2. Untuk semua santri yang ada di Pondok Pesantren, diharapkan untuk selalu menyadari akan pentingnya belajar kitab kuning, supaya dapat mengembangkan ajaran Islam dan mengatasi permasalahan yang ada dengan mengedepankan kemaslahatan umat tanpa harus keluar dari jalur al-Quran dan al-Hadits. Dengan belajar kitab kuning maka akan mengetahui mata rantai sejarah dan budaya ilmiah yang sudah dibangun berabad-abad oleh ulama terdahulu.

3. Untuk semua masyarakat baik di Pondok Pesantren maupun di luar Pondok Pesantren, diharapkan kitab kuning menjadi sebagai referensi dalam mensikapi segala tantangan hidup, serta sebagai arena inovasi untuk menanggapi dunia modern.

4. Untuk penerbit atau percetakan kitab kuning, diharapkan supaya mempertahankan format cetakannya masih tetap sama seperti dahulu yaitu secara umum tidak dijilid atau dibungkus kulit sampul dan kertasnya masih berwarna kuning. Agar karakteristik fisik dari kitab kuning tersebut, yang pada umumnya tetap mengandung makna simbolik, dan agar kelihatannya lebih klasik.

5. Untuk Perpustakaan, diharapkan untuk tetap menyediakan koleksi kitab kuning atau literatur keislaman dalam konteks pesantren secara lengkap, agar pemustaka yang membutuhkan informasi tentang kitab kuning tersebut, mudah untuk menemukannya.

\section{Daftar Pustaka}

Barton, Greeg. (2006). Biografi Gus Dur. Yogyakarta: Lkis.

Bawani, Imam. Dkk. Pesantren Buruh Pabrik: Pemberdayaan Buruh Pabrik Berbasis Pendidikan Pesantren. Yogyakarta: PT. LkiS Printing Cemerlang. 2011. 
E.W. Lane. (1984). Vol. H. Arabic-English Lexion. Cambridge. Lexion.

Haedani, Amin. dkk. (2004). Masa Depan Pesantren: dalam Tantangan Modernitas dan Tantangan Komplesitas Global. IDR Press.

Hak, Nurul. Sains (2015). Kepustakaan, Perpustakaan dan Peradaban dalam Dunia Islam (Klasik, Pertengahan, Modern). Ilmu Perpustakaan dan Informasi Pasca Sarjana UIN Sunan Kalijaga Yogyakarta.

Hasyim, Yusuf. (1995). "Peranan dan Potensi Pesantren dalam Pembangunan" dalam Manfred Oepen dan Wolfgang Karcher (ed), diterj. Shonhadji. Dinamikan Pesantren Dampak Pesantren dalam Pendidikan dan Pengembangan Masyarakat. Surabaya: Hikmah Surabaya.

H.M, Muhtarom. (2005). Reproduksi Ulama di Era Global: Resistansi Tradisional Islam. Yogyakarta: Pustaka Pelajar.

Hsubky, Badruddin. (1995). Dilema Ulama dalam Perubahan Zaman. Jakarta: Gema Insani Press.

http:/ / kumpulanliteratur.blogspot.co.id/2011/11/pengertianliteratur.html. Diakses pada tanggal 23 November 2017. Pukul 16.04. WIB.

http://repository.usu.ac.id/bitstream/123456789/45996/5/Chap ter\%20I.pdf. Diakses pada tanggal 23 November 2017. Pukul 09.07. WIB.

Lasa HS. (2009). Kamus Kepustakawanan Indonesia. Yogyakarta: Pustaka Book Publisher.

Mahfudh, Sahal. (2004). Nuansa Figh Sosial. Yogyakarta: LKIS. Hlm. xxxix.

Mastuhu. (1994). Dinamika Islam Pendidikan Pesantren. Jakarta: INIS.

Mastuki. Dkk (2005). Manajemen Pondok Pesantren. Jakarta: Diva Pustaka.

Mas'udi. (1986). Direktori Pesantren. Jakarta: P3M.

Mcdonald, D.B. (1987). First Encyclopaedia Of Islam 1913-1936. Leiden EJ Brill. 19

Nasir, Ridlwan. (2005). Mencari Tipologi Format Pendidikan Ideal: Pondok Pesantren di Tengah Arus Perubahan. Yogyakarta: Pustaka Pelajar.

Nuha, Shafihun. (2010). Skripsi: Pesantren Berwawasan Multikulturalisme Studi Kasus Pondok Pesantren Edi Mancoro Desa Gedangan Kecamatan Tuntang Kabupaten Semarang. Jurusan Tarbiyah Program Studi Pendidikan Agama Islam Sekolah Tinggi Agama Islam Negeri (STAIN) Salatiga Tahun 2010.

Sari, Nursukma. (2004). "Ulama dan Institusi Pendidikan Islam (Knowledge And Power)". E-Jurnal Studi Bahasa dan Sastra Arab Universitas Sumatera Utara. 
Tabloid Pondok Pesantren Edisi Kedua. (2009). Pramuka Santri yang Semakin Menggigit. Tanggerang: Lekdis Nusantara.

Van Bruinessen, Martin. (1995). Kitab Kuning Pesantren dan Tarekat: Tradisi-Tradisi Islam di Indonesia. Bandung: Mizan.

Wahid, Abdurrahman. (1995). "Prospek Pesantren Sebagai Lembaga Pendidikan", dalam Manfred Oepen dan Wofgang Karcher (ed), diterjemahkan. Shonhadji, Dinamika Pesantren: Dampak Pesantren dalam Pendidikan dan Pengembangan Masyarakat. Surabaya: Hikmah. 